\title{
THE CREATIVE PARADIGM: A BENCHMARK FOR ECONOMIC GROWTH
}

\author{
VALERIE KUPKE \\ University of South Australia
}

\begin{abstract}
Richard Florida in his two best selling books, The Rise of the Creative Class (2002) and The Flight of the Creative Class (2004) proposed a new paradigm for economic growth based on the concept that city and regional economic growth is aligned to specific demographic characteristics. These characteristics are recognised as a form of social or creative capital and are considered necessary for the innovation required to promote economic growth; for instance, in the high technology sector. Creative capital theory states that where creative people live, the economy grows faster - which is to say that jobs follow people. Governments have been keen to incorporate the notion of a creative index into their strategic planning as a means of benchmarking their ability to attract industry and increase high technology opportunities. This paper will examine what is meant by the "creative class" and attempt as an exploratory exercise to identify any relationship between an index measuring creativity with economic and social indicators for the sixty five economic regions in Australia.
\end{abstract}

Keywords: Creative class, innovation, economic growth.

\section{INTRODUCTION}

While cities and economies have been recognised as important to each other for some time (Prud'homme, 1995), the impact of growth on the welfare of cities has been a particular focus (O'Connor \& Stimson, 1994). Structural change within an economy could dramatically affect cities and such places were termed cities in transition (Hayes \& Bunker, 1995). Associated with post fordist urban transition were new concepts of labour, new modes of information, and new conditions for economic growth. Cities, location and place were transcended by new modes of information, technology and production which looked for comparative advantage wherever it could be achieved (Yue-man, 1995; O’Brien, 1992; Dicken, 1992).

There was recognition of a new set of productive factors. Innovation, knowledge and ideas were no longer viewed as exogenous variables, but as key drivers which could 
systematically explain economic growth (Porter, 1990). Innovation occurred when a new or changed product was introduced or when a new or changed process was introduced. It was achieved best by specialization and dense networks of interrelated firms and workers were most competitive; the cluster based theory of economic growth. Workers related by industry, occupation, age or education worked best when spatially close. The highly educated, working in technology and innovative industries, also tended to accumulate knowledge and new ideas best through face to face contact in dense urban areas (Jacobs ,1984).

This recognition of the economic benefits of agglomeration especially in the innovation and technology sectors has continued. At a time when comparative advantage is being lost by developed economies, there has been a shift back to recognizing the role cities play in national economies. The new focus recognises the importance of place, space, location (Berry, 2004). Cities are being described as "magnets", "sticky places", "hot spots" (Sokol, 2004). There is recognition of the economic importance both of cities and of the regions in which they are located. There has been a shift to competitive advantage where competence, innovation, intellectual capacity are key factors in production. Within such an economy, knowledge and intelligence replace physical labour as the main source of value. People are described as human capital. They add value by means of their innovation, their ideas, their imagination, and their creativity. This capital must be captured and cosseted if there is to be national prosperity. And such factors, that is people with ideas, appear to work best when clustered or agglomerated, as did firms, into knowledge cities or regions of life long learning.

Another key to success is specialization. Cities that specialize win, firms that cluster succeed. And people who crowd together in cities to interface and take advantage of "thick" labour markets, produce the ideas, innovation and technology that are the new sources of economic growth (Sawicki, 2003).

However, technology and innovation may not be enough to ensure economic growth. There must also be culture and social capital (Landman, 2004). Social capital refers to the relationships between people, their lifestyles, their recreation and cultural pursuits. It includes networks between institutions, governing bodies and local governments. Urban areas must be able to nurture and support social capital if they are to attract the human capital they need to succeed. Social capital is enhanced by openness, tolerance, and difference within a society and by spontaneity and uniqueness within places. It would appear that cities and regions must be able to offer not just quality of life, but quality of place in order to win. This is the new paradigm for economic growth proposed by Richard Florida in his two best selling books, The Rise of the Creative Class (2002) and The Flight of the Creative Class (2004). 


\section{THE CREATIVE CLASS}

According to Florida, there are three conditions that encourage economic growth in the post-industrial economy; technology, talent and tolerance. These traits are embodied in a new assemblage of workers termed by Florida as the creative class (2002). These are the scientists, engineers, architects, educators, writers, artists and entertainers whose function it is to generate new ideas, technologies and creative content. Florida breaks down the creative class into a super creative core which includes engineers, scientists, artists, professors and technology innovators. They are backed up by the creative professionals who use the knowledge in their work, including managers, lawyers, financial experts, health care professionals and technicians. In the USA where Florida is based, the combined group represents about 30 percent of the workforce (Florida, 2002). People in Florida's creative class are not necessarily highly educated. According to Florida (2002), the key to understanding urban and regional economic growth is not a high level of education, but creativity. Florida is designing categories for people who are not necessarily highly educated, yet are very important for economic production and growth.

Florida proposes that cities and regions are competitive because of the creative numbers they contain (Florida, 2002, 2004). His creative capital theory states that where creative people live, the economy grows faster - which is to say that jobs follow people. In brief, tolerance attracts talent which attracts technology. Place is fundamentally important. It is what draws creative people to a city. However, creative people are attracted most to places which are lively and open with physical and social environments that show character and distinctiveness. The creative class make their location choices based on "What's there?", "Who's there?", "What's going on?" (Berry, 2004). They value time and hence accessibility. They seek functional homes and easy access to airports. The inner city is most attractive for living and for work. They value infrastructure, as well as culture and place as much as style.

Florida has created a series of indices that highly correlate with economic growth (2002). His Creative Index is based on four factors. These include the proportion of the workforce based in certain occupations; innovation as measured by patent activity; the high technology share of the economic base; and diversity, a factor which is based on measurements related to sexual orientation, bohemian lifestyles (cutting edge or counter culture) and diversity (foreign born). By assembling data and constructing a variety of indices, Florida has ranked metropolitan regions in the USA and across the world according to a creativity index. This he regards as the most accurate gauge of a city's ability to generate new ideas, high tech business and regional growth (Florida, 2004).

He then correlates the index with a city or region's economic performance. For the USA, Florida finds a high positive correlation between cities that rank high on the Creative Index and cities that are prosperous in terms of growth of regional product and employment and 
rising average earnings. His conclusion is that employment growth can be predicted from the presence of a large creative class.

Writers acknowledge that while Florida's recognition of the economic role of cities is not new, his contribution to regional analysis is significant (Blakely, 2004; Berry, 2005). Economists have long identified that agglomeration economies establish efficiencies and comparative advantage occurs when firms cluster in geographic space (Berry, 2003; Porter, 1990). Florida's job growth in the new information economy is strongly correlated with labour force characteristics that match up with the traditional requirements of technologybased employment. Research does indicate that some cities in the USA such as Boston, San Francisco and Austin have attracted a large percentage of creative talent from other parts of the USA (Blakely, 2004).

Florida rates metropolitan areas on a creativity index which places San Francisco first, Austin second, San Diego and Boston equal third and Seattle fourth. Florida has also calculated that creative occupations make up fully half the workforce in both central Sydney (51.1 percent) and central Melbourne (49.5 percent); far greater than in virtually any inner city in the USA. Sydney and Melbourne would rank fourth or fifth if they were USA regions. Florida has also estimated (2004) that the creative class constitutes around a third of the workforce in "hot spots" such as Ireland, Belgium, Australia and the Netherlands, and accounts for about one quarter of the workforce in six other countries including New Zealand, Estonia, the UK, Canada, Finland and Iceland.

Since 1991, New Zealand's creative class has jumped from 18.7 percent to 27.1 percent and Ireland's has nearly doubled from 18.7 percent to 33.5 percent. The creative class makes up 38.1 percent of Wellington's workforce and 31 percent of Auckland's. Wellington's proportion of the super creative core is 20 percent, Dunedin's 18.7 percent, Palmerston North 18 percent, Hamilton 16.7 percent and Auckland 16.5 percent. Florida (2004) believes that these cities and regions will be important in attracting the new creative classes that may well abandon the USA.

\section{CREATIVE VISION}

Berry (2005) describes Florida's approach as "persuasive" and acknowledges that it resonates with policy makers. State governments, city councils and city regions have looked to this new paradigm as a convincing means of invigorating their local economies. Members may not appreciate input-output tables, econometrics or structural equations, but local councils and regional committees understand people. They know their local regions and can identify lifestyle and place advantages. They understand promotion. And so, cities in the USA, Australia, New Zealand and Europe have been keen to benchmark their creative talent, identify ways to make it grow and then plan for the firms and businesses it will attract. 
City such as Palmerston North (New Zealand) state in their strategic plan:

"Together we will make Palmerston North an exciting city in which to live, learn, work play. Ours will be a caring community where differences are valued. Education, research and knowledge will be our strengths. Our goal is to be a recognised leader in life long learning. We strive to be creative in work and skillful in business."(Palmerston North Vision Statement, 2002)

Arlington (USA) states that their city "will be a diverse and inclusive world class urban community with secure attractive, residential and commercial neighbourhoods where people unite to form a caring, learning, participating, sustainable community."(Arlington County Board, 2002)

The South Australian Government in its Strategic Plan (2004) states:

"Our priority is to reinforce South Australia as a place that thrives on creativity and innovation. The capacity to do things differently will be one of the keys to achieving our objectives. The focus will be on fostering a culture of creativity, on developing creative, innovative and enterprising people." (SA Strategic Plan, 2004)

The South Australian State Government wishes to achieve a ranking in the top three regions of Australia, using Florida's creative index, within 10 years (SA, 2004). Based on the fundamentals that Florida uses within his index, they also want patent applications within South Australia to exceed per capita share within five years. They seek a growing share of the national film industry, wish to increase the number of families in life-long learning, improve learning outcomes in the fine arts and have introduced an international "Thinker in Residence" scheme.

\section{CREATIVITY AND GROWTH}

In an effort to quantify any association between creativity and economic growth at the most basic level, bivariate correlation was applied to Australian Local Government Association (ALGA) data obtained from National Economics State of the Regions Report (ALGA, 2002) for each of the sixty-four economic regions within Australia as defined by National Economics. In the main, these regions represent statistical divisions as established by the Australian Bureau of Statistics (ABS). Others are an amalgamation of ABS statistical divisions and state planning regions (ALGA, 2001). The regional classification includes nine core metropolitan regions, such as Adelaide Central, Brisbane City, Melbourne Inner, Darwin, Global Sydney; and thirteen dispersed metropolitan regions such as Adelaide Outer, Brisbane North, Melbourne East, Brisbane North, Sydney Outer North, and the NSW Central Coast. The data is sourced from the National Institute for Economic and Industry Research (NIEIR) and includes growth in employment between 1998 and 2002, population and business income between 1998 and 2002, change in housing affordability between 1996 and 2002, the proportion of unemployed families and very poor households in 2002 and the proportion of workers aged 15 to 34 years who were earning more than $\$ 50,000$ in 2001 (ALGA, 2002). These measurements have been correlated with the NIEIR 
Creative Index for each region (ALGA, 2002), as well as the percentage of the population classified by occupation as part of the Creative Core and/or the Creative Class. The NIEIR Creative Index is based on a ranking of each region according to its level of innovation, high-tech activity, diversity and proportion of the creative class as of 2001 (ALGA, 2002). Percentages measuring the Creative Core and the Creative Class are sourced from the Australian Bureau of Statistics (ABS) 2001 Census of Population and Housing.

Significant associations as measured by Pearson's correlation coefficient are indicated in Table 1. The direction of most of the significant associations ( 2 tailed) is as expected. For the 64 economic regions, the NIEIR Creative Index is positively associated with population growth between 1998 and $2002(\mathrm{r}=.542)$ and in the proportion of 15 to 34 year olds earning more than $\$ 50,000$ per annum $(\mathrm{r}=.432)$. It is correlated negatively with change in housing affordability between 1996 and $2002(\mathrm{r}=-.587)$ and the proportion of very poor households within a region as of $2001(\mathrm{r}=-.443)$. However, while it is negatively associated with long term or structural unemployment $(\mathrm{r}=-.699)$, and is significant against increase in business income between 1998 and $2002(\mathrm{r}=.452)$, it is not significant against employment growth between 1998 and 2002. This would appear to contradict the Florida paradigm which suggests that a creative environment in terms of people, place and lifestyle prompts job growth.

These associations are supported when items are also measured against the proportion of the population engaged in occupations deemed to be part of the Creative Core (computer, maths, architecture, engineering, life, physical and social sciences, education, training and library occupations, arts, design, entertainment, sports and media occupations) or the Creative Class (Creative Core plus management, business and financial legal, healthcare and technical, high end sales and sales management occupations) (Table 1). Again, these items while positively associated with growth in business income $(r=.492 ; r=.545)$, are not significant against employment growth between 1998 and 2002. The strongest positive association is between the Creative Core and those young persons aged 15 to 34 years earning more than $\$ 50,000$ per annum $(r=.644)$. As one is likely to be a subset of the other this is largely a redundant finding. The strongest negative finding is between the Creative Index and structural unemployment growth $(\mathrm{r}=-.699)$. 
Table 1: Australia - ALGA Regions

\begin{tabular}{|c|c|c|c|}
\hline $\begin{array}{l}\text { Australia LGA } \\
\text { Regions (N=64) }\end{array}$ & $\begin{array}{l}\text { Creative Index } 1 \\
\text { (65=highest, } 1= \\
\text { lowest) }\end{array}$ & $\begin{array}{l}\text { Creative } \\
\text { Core }_{2}\end{array}$ & $\begin{array}{l}\text { Creative } \\
\text { Class }_{3}\end{array}$ \\
\hline $\begin{array}{l}\text { Population \% p.a. growth } \\
1998-2002_{a}\end{array}$ & $.542^{\star \star}$ & $.267^{*}$ & $.351^{\star \star}$ \\
\hline $\begin{array}{l}\text { Employment growth \% } \\
\text { p.a. growth } 1998-2002 \text { b }\end{array}$ & .207 & .151 & .212 \\
\hline $\begin{array}{l}\text { Structural unemployment } \\
\% \text { p.a. growth } 1998-2002_{c}\end{array}$ & $-.669 * \star$ & $-.500^{\star \star}$ & $-.561^{\star \star}$ \\
\hline $\begin{array}{l}\text { Business income \% p.a. } \\
\text { growth } 1998-2002_{d}\end{array}$ & $.452^{\star \star}$ & $.492^{\star \star}$ & $.545^{\star \star}$ \\
\hline $\begin{array}{l}\text { House price affordability } \% \\
\text { change } 1996-2002 \mathrm{e}\end{array}$ & $-.587^{\star * *}$ & $-.442^{\star *}$ & $-.465^{\star \star}$ \\
\hline $\begin{array}{l}\text { Aged } 15-34 \text { years income } \\
\$ 50+k \% \text { persons }_{f}\end{array}$ & $.432^{\star \star}$ & $.644^{\star \star}$ & $.603^{\star \star}$ \\
\hline $\begin{array}{l}\text { Unemployed families \% } \\
\text { households } s_{g}\end{array}$ & -.176 & $-.332^{* *}$ & $-.460 \star \star$ \\
\hline $\begin{array}{l}\text { Very poor families \% } \\
\text { householdsh }\end{array}$ & $-.443^{\star \star}$ & $-.574^{\star \star}$ & $-.630^{\star *}$ \\
\hline
\end{tabular}

** significant at 0.01 level (2 tailed) *significant at 0.05 level (2 tailed)

a ABS Estimated resident population series (ERP) (Source: NIEIR, 2002)

b Dept of Employment, Workplace Relations \& Small Business (DEWRSB) (Source: NIEIR, 2002)

c Centrelink long termed unemployed (Source: NIEIR, 2002)

d Taxation Dept Canberra (Source: NIEIR, 2002)

e Valuer General SA, NSW, Vic, WA, NT, QId, Tas, ACT (Source: NIEIR, 2002)

f $A B S$ Census 2001 (Source: NIEIR, 2002)

gased on ABS Household Expenditure Survey 1998-99 (Source: NIEIR, 2002)

h Based on ABS Household Expenditure Survey 1998-99 (Source: NIEIR, 2002)

${ }_{1}$ Creative Index based on calculation of innovation, high-tech activity, diversity, creative class (Source: NIEIR, 2002)

${ }_{2}$ Creative Core ABS Census 2001 Computer, maths, architecture, engineering, life, physical \& social sciences, education, training \& library occupations, arts, design, entertainment, sports \& media occupations (Source: NIEIR, 2002)

3 Creative Class ABS Census 2001 Creative Core + Management, business \& financial legal, healthcare \& technical, high end sales and sales management occupations (Source: NIEIR, 2002) 
The same items were then measured against the nine major metropolitan areas in Australia (Table 2). These are the types of regions for which Florida has had a particular focus (Florida, 2002). The NIEIR Creative Index is only positively correlated with increases in business income $(\mathrm{r}=.959)$. It is negatively correlated with structural unemployment $(\mathrm{r}=-.748)$, housing affordability $(\mathrm{r}=-.854)$, unemployed families $(\mathrm{r}=-.693)$ and very poor households $(\mathrm{r}=-.707)$. It is not significantly associated with population or employment growth.

For the 15 dispersed significant urban areas in Australia, regions that are likely to be very interested in employment growth opportunities, the Creative Index is only positively correlated with persons 15 to 34 years that are earning more than $\$ 50,000$ per annum (Table 3). It is negatively correlated with structural unemployment, housing affordability, unemployed families and very poor households. Again, it is not significant against population or employment growth. 
Table 2: Australia - ALGA Core Metropolitan Regions

\begin{tabular}{|c|c|c|c|}
\hline $\begin{array}{l}\text { Australia Core } \\
\text { Metropolitan }(\mathrm{N}=9)\end{array}$ & $\begin{array}{l}\text { Creative Index } 165= \\
\text { highest, } 1=\text { lowest) }\end{array}$ & $\begin{array}{l}\text { Creative } \\
\text { Core }_{2}\end{array}$ & $\begin{array}{l}\text { Creative } \\
\text { Class }_{3}\end{array}$ \\
\hline $\begin{array}{l}\text { Population \% p.a. growth } \\
\text { 1998-2002a }\end{array}$ & .151 & -.088 & .074 \\
\hline $\begin{array}{l}\text { Employment growth \% } \\
\text { p.a. growth 1998-2002b }\end{array}$ & .024 & .126 & -.024 \\
\hline $\begin{array}{l}\text { Structural unemployment } \\
\% \text { p.a. growth } 1998-2002_{c}\end{array}$ & $-.748^{*}$ & -.166 & -.249 \\
\hline $\begin{array}{l}\text { Business income \% p.a. } \\
\text { growth } 1998-2002_{d}\end{array}$ & $.959 \star \star$ & .637 & $.701^{\star}$ \\
\hline $\begin{array}{l}\text { House price affordability } \\
\% \text { change1996-2002 }\end{array}$ & $-.854^{\star \star}$ & -.530 & -.633 \\
\hline $\begin{array}{l}\text { Aged } 15-34 \text { years income } \\
\$ 50+k \% \text { persons } f\end{array}$ & .592 & .616 & $.687^{*}$ \\
\hline $\begin{array}{l}\text { Unemployed families \% } \\
\text { households }_{\mathrm{g}}\end{array}$ & $-.693^{\star}$ & -.593 & $-.732^{\star}$ \\
\hline $\begin{array}{l}\text { Very poor families } \% \\
\text { households }\end{array}$ & $-.707^{\star}$ & $-.709^{\star}$ & $-.771^{\star}$ \\
\hline
\end{tabular}

** significant at 0.01 level (2 tailed) *significant at 0.05 level (2 tailed)

a ABS Estimated resident population series (ERP) (Source: NIEIR, 2002)

b Dept of Employment, Workplace Relations \& Small Business (DEWRSB) (Source: NIEIR, 2002)

c Centrelink long termed unemployed (Source: NIEIR, 2002)

¿ Taxation Dept Canberra (Source : NIEIR, 2002)

e Valuer General SA, NSW, Vic, WA, NT, QId, Tas, ACT (Source: NIEIR, 2002)

${ }_{f}$ ABS Census 2001 (Source: NIEIR, 2002)

g Based on ABS Household Expenditure Survey 1998-99 (Source: NIEIR, 2002)

$\mathrm{h}$ Based on ABS Household Expenditure Survey 1998-99 (Source: NIEIR, 2002)

${ }_{1}$ Creative Index based on calculation of innovation, high-tech activity, diversity, creative class (Source: NIEIR, 2002)

${ }_{2}$ Creative Core ABS Census 2001 Computer, maths, architecture, engineering, life, physical \& social sciences, education, training \& library occupations, arts, design, entertainment, sports \& media occupations (Source: NIEIR, 2002)

3 Creative Class ABS Census 2001 Creative Core + Management, business \& financial legal, healthcare \& technical, high end sales and sales management occupations (Source: NIEIR, 2002) 
Table 3: Australia - ALGA Dispersed Metropolitan Regions

\begin{tabular}{|c|c|c|c|}
\hline $\begin{array}{l}\text { Australia Dispersed } \\
\text { Metropolitan }(\mathrm{N}=15)\end{array}$ & $\begin{array}{l}\text { Creative Index } 1 \\
\text { Rank (65 = } \\
\text { highest,1 = } \\
\text { lowest) }\end{array}$ & Creative Core $_{2}$ & $\begin{array}{l}\text { Creative } \\
\text { Class }_{3}\end{array}$ \\
\hline $\begin{array}{l}\text { Population \% p.a. growth 1998- } \\
2002_{a}\end{array}$ & -.276 & -.403 & -.341 \\
\hline $\begin{array}{l}\text { Employment growth \% p.a. } \\
\text { growth 1998-2002 }\end{array}$ & -.393. & -.084 & -.267 \\
\hline $\begin{array}{l}\text { Structural unemployment \% } \\
\text { p.a. growth } 1998-2002_{c}\end{array}$ & $-.744^{\star *}$ & $-.563^{\star}$ & $-.698^{\star *}$ \\
\hline $\begin{array}{l}\text { Business income \% p.a. growth } \\
\text { 1998-2002 }\end{array}$ & .385 & $.702^{\star \star}$ & $.751^{\star *}$ \\
\hline $\begin{array}{l}\text { House price affordability } \% \\
\text { change } 1996-2002_{\mathrm{e}}\end{array}$ & $-.673^{\star \star}$ & $-.549^{\star}$ & -.448 \\
\hline $\begin{array}{l}\text { Aged } 15-34 \text { years income } \\
\$ 50+k \% \text { persons }_{f}\end{array}$ & $.753^{\star \star}$ & $.747^{\star *}$ & $.878^{\star *}$ \\
\hline $\begin{array}{l}\text { Unemployed families \% } \\
\text { householdsg }\end{array}$ & $-.654^{\star \star}$ & -.399 & $-.743^{\star *}$ \\
\hline $\begin{array}{l}\text { Very poor families } \% \\
\text { households }\end{array}$ & $-.777^{\star \star}$ & $-.578^{\star}$ & $-.866^{\star *}$ \\
\hline
\end{tabular}

** significant at 0.01 level (2 tailed) *significant at 0.05 level (2 tailed)

${ }_{a}$ ABS Estimated resident population series (ERP) (Source: NIEIR, 2002)

b Dept of Employment, Workplace Relations \& Small Business (DEWRSB) (Source: NIEIR, 2002)

c Centrelink long termed unemployed (Source: NIEIR, 2002)

¿ Taxation Dept Canberra (Source : NIEIR, 2002)

e Valuer General SA, NSW, Vic, WA, NT, QId, Tas, ACT (Source: NIEIR, 2002)

† ABS Census 2001 (Source: NIEIR, 2002)

$\mathrm{g}$ Based on ABS Household Expenditure Survey 1998-99 (Source: NIEIR, 2002)

${ }_{n}$ Based on ABS Household Expenditure Survey 1998-99 (Source: NIEIR, 2002)

${ }_{1}$ Creative Index based on calculation of innovation, high-tech activity, diversity, creative class (Source: NIEIR, 2002)

${ }_{2}$ Creative Core ABS Census 2001 Computer, maths, architecture, engineering, life, physical \& social sciences, education, training \& library occupations, arts, design, entertainment, sports \& media occupations (Source: NIEIR, 2002)

3 Creative Class ABS Census 2001 Creative Core + Management, business \& financial legal, healthcare \& technical, high end sales and sales management occupations (Source NIEIR 2002) 


\section{CONCLUSION}

The analysis in this study is simple and few in the way of conclusions can be drawn. It attempts merely to replicate the correlations that have been proposed by Florida. An inherent weakness is that correlation only identifies association. No causality can be inferred. Are cities successful because they attract creative people or are creative people attracted to successful places? On the other hand, Florida has identified important and highly correlated associations which policy makers understand. A longer time period and lagging of items may provide a stronger association between creativity and employment growth within Australia. However, policy based solely on such correlation is likely to be highly simplistic and badly specified (Berry, 2005). Casual relationships between items such as business growth and innovation need to be explored and if possible the mechanics of the causality identified.

As well, Florida does not factor in the spatial aspects of urban development; the where of city development as well as the when. Berry (2005) writes that Florida largely ignores the "systematic linkages, hierarchies and asymmetrics between urban centers and the very different histories of each".

There is also a problem with the social context. Florida writes of community and tolerance. Yet the number of gated communities both in the USA and in the UK is on the rise (Minton, 2004). Some 12 per cent of the US population live in neighbourhoods which have walls and regular security patrols (Minton, 2004). The number of such communities is also increasing in the UK especially in cities such as London, a creative hot spot, as a result of social polarization, mutual suspicion, demand for greater security and fear of rising crime. We may be entering an era where the factors that Florida suggests promote growth such as tolerance, cultural diversity and integration may become rare as urban commodities.

Another issue is that of housing affordability which can be a significant drag on fostering creativity and job growth. Florida acknowledges this as a critical issue which needs to be addressed if regional growth is to be sustained (Florida, 2004; Minton, 2002; Jones, 2002). Especially the provision of affordable housing for those in the creative classes such as health care workers and education professionals who are not high income earners, but are key workers for a growing city economy (ODPM, 2005).

Policy advocates themselves have suggested that if growth based on creativity and community is to be sustained, then decisions need to be made which are inclusive of everyone, not just those who are part of the knowledge elite. There are renewed calls for community housing, not just affordable housing. In the UK, property professionals (Brooke, 2004) and government (ODPM, 2005) have recognised the creative imperative and have called for urban renewal to retain the souls of places (Chambers, 2004). They suggest housing developments should use cultural projects to promote image and personality of place. They recognise that for cities to be competitive they must be able to 
contribute to the knowledge economy and recommend that policy makers and planners use lifestyle as a lever to attract certain kinds of workers to a city or region.

In terms of Australia, there could be doubts as to whether this creative paradigm can be accommodated within an urban hierarchy dominated by so few major cities. There may be just too few core metropolitan areas for any knowledge agglomeration to occur. Questions could also be raised as to how much is actually known about the residential and location choices of those who make up the creative class. Their choices may reflect a wider generational trend in favour of functionality, mobility and time saving. However, on a more positive note, the emphasis within this paradigm on diversity, independence and tolerance is an excellent backdrop in the promotion of community-based housing. This form of housing which may be church or local community based is seen as achievable in the UK (Brook, 2004) and an important step up on housing affordability targets.

\section{REFERENCES}

Australian Local Government Association (ALGA) and National Economics (NIEIR) (2001) State of the Regions Report 2002, ALGA ACT.

Australian Local Government Association (ALGA) and National Economics (NIEIR) (2002) State of the Regions Report 2002, ALGA ACT.

Berry M (2005) Melbourne-Is there life after Florida? Urban Policy and Research, Vol 23 No 4 pp381-392.

Berry M (2003) Innovation by design: the economic drivers of dynamic regions. lab3000 Report RMIT, Melbourne.

Blakely E (2004) Regional science cyclops - from a one eyed view to two eyed view. Australasian Journal of Regional Studies, Vol 10 No 3 pp 265-277.

Brooke N (2004) What makes for a successful city? Winning Cities, RICS Conference Shanghai, Beijing February 2004.

Chambers M (2004) Affordable housing. RICS 2004.

Dicken P (1992) Global Shift. Chp 2 The changing global map: trends in production and trade. pp 16-45.

Florida $\mathrm{R}$ (2002) The rise of the creative class and how it is transforming work, leisure, community and every day life. Pluto Press, Melbourne.

Florida R (2004) The flight of the creative class. Harper Business, New York. 
Hayes D and Bunker R (1995) The changing role of the city centre in Adelaide and Melbourne Urban Policy and Research, Vol 13 No 3 pp 159-171.

Jacobs J (1984) Cities and the wealth of nations. Economic Press.

Jones C (2002) Rent to buy schemes. ODPM 2002.

Landman J (2004) Social capital: a building block creating a better future. Foresight, Vol 6 No 1 pp 38-46.

Minton A (2004) Mind the gap; tackling social polarisation through balance communities. RICS 2004.

O'Brien, R (1992) Global financial integration: the end of geography. Chp 2: Information Technology and Global Finance pp 7-16.

O'Connor K and Stimson R (1994) Economic change and the fortunes of Australian cities Urban Futures, pp 1-11.

ODPM (Office of Deputy Prime Minister) (2005) Our cities are back. ODPM London.

Porter M (1990) The competitive advantage of nations. The Free Press, New York.

Prud'homme R (1995) On the economic role of cities. Urban Futures, No 19, pp 24-33.

South Australia (SA) State Government (2004) State Strategic Plan Adelaide South Australia. AGPS.

Sawicki D (2003) APA Journal. Vol 69 No 1 pp 90 -91.

Sokol M (2004) City regional governance: on conceptual issues. City futures an international conference on globalism and urban change. 8-10 $0^{\text {th }}$ July 2004 Chicago.

Yeung Y (1995) Pacific Asia's world cities in the new global economy. Urban Futures, No 19 pp 81-91. 